\title{
A Visit from the Old Mistress (Oil on Canvas by Winslow Homer)
}

Florence Ladd

Why has she come from over yonder? She calls up our miseries on her plantation, ploughing her fields, picking her cotton, nursing her children, our own neglected for their ease. She ain't sorry for her ways, just sorry we done quit slaving.

Crossing the sill of our cabin, she opens old wounds: our meals her leftovers, our clothes rags from her trunks; harsh words, hard work; thrashings; rape of our daughters, sale of our sons, stillness of hanging bodies at carnival lynchings we were forced to see. Our hearts heavy, hers stony.

Dare she tarry?
Why won't they come to see me? Poor piccaninies turned ornery now manumitted, they took leave of my God forsaken plantation forgetting the years I took care of them, by rights my property.

Crossing these fields gone fallow as cotton rots and vultures flock, I reckon I'll not redeem the land, stand proud again without hands black and quick to plant and pick. Bereft, lonesome, and weary, I need their shiftless company. But dare I tarry?

\section{Note}

1. The reader may view Homer's painting at the Smithsonian American Art Museum of the Smithsonian Institution in Washington, DC. Visit the Smithsonian Web site, “CivilWar@Smithsonian," under “Slavery and Abolition," http://www.civilwar. si.edu/slavery_visit.html. 